\title{
ANALYSIS OF RESULTS ASSESSMENT OF GROWTH RATES OF SIMMENTAL BEEF CATTLE IN POLAND
}

\section{ANALIZA WYNIKÓW OCENY WZROSTU BYDŁA RASY SIMENTAL W POLSCE}

\author{
Department of Animal Breeding, Warsaw University of Life Sciences, Poland
}

\begin{abstract}
Streszczenie. Celem pracy była analiza wybranych wyników oceny użytkowości rasy simental w odniesieniu do ich zgodności z celem hodowlanym i standardami rasowymi przyjętymi przez Polski Związek Hodowców i Producentów Bydła Mięsnego (PZHiPBM). Przedmiotem analiz były wyniki oceny użytkowości rasy bydła mięsnego rasy simental w Polsce. Opracowanie oparto na danych PZHiPBM z lat 2002-2013 oraz Krajowego Centrum Hodowli Zwierząt $(\mathrm{KCHZ}) \mathrm{z}$ lat 1996-2001. Oceniano średnią masę ciała krów [kg], średnią masę ciała cieląt po urodzeniu [kg], terminy ocieleń krów i jałowic, rozkład populacji krów według kolejności ocielenia. Można zaobserwować znaczny spadek liczby mieszańców z rasą simental. Średnia masa krów w latach 2005-2006, wynosząca odpowiednio 569 i 523 kg, spełnia standardy hodowlane dla krów wpisywanych do części wstępnej księgi hodowlanej, które określają minimalna mase ciała krowy rasy simental po 1 . ocieleniu na $470 \mathrm{~kg}$. Średnia masa ciała przy urodzeniu jałówek w poszczególnych latach oceny była zbliżona, ale po roku 2009 zmniejszyła się poniżej $33 \mathrm{~kg}$. U buhajków czystorasowych obserwowano systematyczny spadek średniej masy urodzeniowej. Różnica średniej masy urodzeniowej między jałówkami a buhajami wynosiła od $1 \mathrm{~kg}$ do $2 \mathrm{~kg}$, w zależności od roku oceny. Uzyskane średnie dobowe przyrosty cieliczek dają gwarancję, że dalsze żywienie, gwarantujące przyrosty dobowe $\mathrm{w}$ granicach 550-560 g, pozwoli na uzyskanie w wieku 15 miesięcy masy ciała pozwalającej na rozpoczęcie użytkowania rozpłodowego.
\end{abstract}

Key words: beef cattle, Simmental, beef cattle recording, average body weight.

Słowa kluczowe: bydło mięsne, simental, ocena użytkowości bydła mięsnego, średnie przyrosty masy ciała.

\section{INTRODUCTION}

Twenty years the Programme of Beef Cattle Breeding Development in Poland finished in 2014 (Jasiorowski et al. 1996). Due to the sparse pure-bred female population is difficult to talk about own national breeding program. Therefore, the maintenance of high standards of breed is the main task of PABPBC. Its implementation is, inter alia, beef recording conducted in cattle herds. The weight of a cow by its relationship with a caliber, has a direct impact on the course of calving (more cows tend to have a larger area of the pelvis channel) and body

Corresponding author - Adres do korespondencji: Tomasz Przysucha, Department of Animal Breeding, Warsaw University of Life Sciences, Ciszewskiego 8, 02-786 Warszawa, Poland, e-mail: tomasz_przysucha@sggw.pl 
weight of calf, which, along with nutrition, has a significant impact on daily gains of calves during rearing. The weight of the calf at birth has an influence not only on the course of calving, but also on the subsequent results of its rearing. Daily gains of calves to 210 days of age determine their body weight at weaning, this in turn has an impact on the profit from the sale of reared calves (mainly bulls), or the cost of winter feeding of heifers for breeding, which must receive the required, minimum weight at the moment their mating at the age of 15 months. Calving season has a direct impact on the cost of maintaining the basic herd (maximum utilization of the entire grazing season) and the quality of breeding calves (health, growth rate). Distribution of cows calving aptitude in order of calving tells us about the longevity of cows, which particularly in the herds of beef cattle is one of the main factors affecting the reduction of costs of the herd.

The aim of the study was to assess the utility of selected results of the Simmental breed with respect to their compliance with the goal of breeding standards adopted by PABPBC. Height at sacrum for females was $135 \mathrm{~cm}$, and $145 \mathrm{~cm}$ for males at maturity and body weight for females $900 \mathrm{~kg}, 1300 \mathrm{~kg}$ for males. An important selection factor is to maintain a high level of milk production and the exclusion of breeding males with a tendency to transmit high weight of calves at birth. Simmental breed in terms of breeding is an excellent paternal line to be crossed and this aspect on a par with good results in pure bred breeding will be given special attention in the course of selection work.

\section{MATERIAL AND METHODS}

The subject of the analysis were beef cattle recording results for the Simmental breed in Poland with respect to their compliance with the goal of racial breeding and standards adopted by the Polish Association of Breeders and Producers of Beef Cattle (PABPBC). The subject of the analysis were recording results of the Simmental beef cattle breed in Poland. The study was based on data for the years 2002-2014 of PABPBC and the National Center of Animal Breeding (NCAB) for 2000-2001. The data set included: $\mathrm{N}$ - the number of animals tested, in. and minimum values in the studied traits, max. and min. value of the selected features, average values of the analyzed traits, SD - standard deviation. Evaluated properties are: average weight of cows [kg], the average body weight of calves after birth [kg], the terms of cows and heifers calving aptitude, the distribution of the population according to the order of calving cows.

The calculation of standardized animal body weight for given day in its life was done according to the following formula:

$\mathrm{MCS}=[(\mathrm{MCB}-\mathrm{MCU}) / \mathrm{WW}] \cdot \mathrm{WS}+\mathrm{MCU}$ where:

MCS - is a standardized animal body weight $[\mathrm{kg}]$,

MCB - mean body weight of the animal on the actual weighing [kg],

$\mathrm{MCU}$ - is the actual body weight set for 48 hours. at birth [kg],

WW - mean age of the animal on the weighing [days],

WS - standardized age of the animal [s]. 


\section{RESULTS AND DISCUSSION}

Table 1 presents the quantitative changes of the female purebred population of Simmental cattle in the years 2000-2014. It should be noted that in 2000-2006 the data included both cows and heifers, and since 2007, the data relate only to cows and excluding heifers. One can observe a gradual decrease in the breed discussed in the national cattle population, also shows a significant decrease in the number of crossbreds with Simmental breed.

Table 1. Quantitative changes of the female population of Simmental cattle in Polanda Tabela 1. Zmiany ilościowe żeńskiej populacji bydła rasy simental w Polsce

\begin{tabular}{|c|c|c|c|c|c|c|c|c|}
\hline \multirow{4}{*}{$\begin{array}{l}\text { Year } \\
\text { Rok }\end{array}$} & \multirow{2}{*}{\multicolumn{3}{|c|}{$\begin{array}{c}\text { Beef breed female population } \\
\text { Żeńska populacja bydła } \\
\text { mięsnego }\end{array}$}} & \multicolumn{5}{|c|}{$\begin{array}{l}\text { Simmental breed } \\
\text { Rasa simental }\end{array}$} \\
\hline & & & & \multirow{3}{*}{$\begin{array}{l}\text { purebred } \\
\text { czysto- } \\
\text { rasowa }\end{array}$} & \multirow{3}{*}{$\begin{array}{l}\text { crossbred } \\
\text { mieszań- } \\
\text { cowa }\end{array}$} & \multirow{3}{*}{$\begin{array}{l}\text { purebred + } \\
\text { crossbred } \\
\text { czysto- } \\
\text { rasowa + } \\
\text { mieszań- } \\
\text { cowa }\end{array}$} & \multirow{2}{*}{\multicolumn{2}{|c|}{$\begin{array}{c}\text { share in the } \\
\text { population } \\
\text { udział w populacji } \\
{[\%]} \\
\end{array}$}} \\
\hline & \multirow[b]{2}{*}{$\begin{array}{l}\text { pure- } \\
\text { bred } \\
\text { czysto- } \\
\text { rasowa }\end{array}$} & \multirow[b]{2}{*}{$\begin{array}{l}\text { cross- } \\
\text { bred } \\
\text { mieszań } \\
\text {-cowa }\end{array}$} & \multirow[b]{2}{*}{$\begin{array}{l}\text { total } \\
\text { razem }\end{array}$} & & & & & \\
\hline & & & & & & & $\begin{array}{l}\text { pure- } \\
\text { bred } \\
\text { czysto- } \\
\text { rasowa }\end{array}$ & $\begin{array}{l}\text { cross- } \\
\text { bred } \\
\text { mieszań } \\
\text {-cowa }\end{array}$ \\
\hline 2000 & 9085 & 9468 & 18553 & 507 & 715 & 1222 & 5.6 & 7.6 \\
\hline 2001 & 9129 & 9748 & 18877 & 530 & 741 & 1271 & 5.8 & 7.6 \\
\hline 2002 & 9735 & 8968 & 18703 & 606 & 555 & 1161 & 5.7 & 6.2 \\
\hline 2003 & 11768 & 9382 & 21150 & 793 & 140 & 933 & 6.7 & 1.5 \\
\hline 2004 & 13884 & 10925 & 24809 & 935 & 187 & 1122 & 6.7 & 1.7 \\
\hline 2005 & 17130 & 11710 & 28840 & 980 & 302 & 1282 & 5.7 & 2.6 \\
\hline 2006 & 19597 & 13100 & 32697 & 1206 & 456 & 1662 & 6.2 & 3.5 \\
\hline 2007 & 14541 & 11676 & 26217 & 851 & 283 & 1134 & 5.9 & 2.4 \\
\hline 2008 & 17481 & 12097 & 29578 & 1008 & 296 & 1304 & 5.8 & 1.7 \\
\hline 2009 & 15435 & 7711 & 23146 & 701 & 123 & 824 & 4.0 & 1.6 \\
\hline 2010 & 16436 & 7576 & 24012 & 618 & 124 & 742 & 3.8 & 1.6 \\
\hline 2011 & 16216 & 7459 & 23675 & 605 & 67 & 672 & 3.7 & 0.9 \\
\hline 2012 & 16724 & 7070 & 23794 & 598 & 66 & 664 & 3.6 & 0.9 \\
\hline 2013 & 17481 & 6633 & 24114 & 502 & 45 & 547 & 2.9 & 0.7 \\
\hline 2014 & 18061 & 6302 & 24363 & 538 & 35 & 573 & 3.0 & 0.6 \\
\hline
\end{tabular}

a From 2007 the list includes only the cows - Od 2007 roku zestawienie obejmuje tylko krowy.

Table 2 shows the mean body weight of purebred Simmental cows in the period in which this trait was evaluated. The average body weight of cows were much smaller than the predefined by PABPBC, according to which the weight of adult cow of discussed breed should be about $830 \mathrm{~kg}$. Average weight of cows in 2005 amounting 569 and $2006523 \mathrm{~kg}$ meet the standards for breeding of cows entered in the initial part of the herd book, which define the minimum weight of Simmental cows after first calving as $470 \mathrm{~kg}$. It should be noted that the average weight of the cow did not change significantly over 8 years of evaluation of this trait, but rather high standard deviations indicate the wide variety of cows of the breed body weight. Genotype and weight of the mother cows are always described among the many factors involved in normal growth and development of calves. Numerous studies have shown that the weight of the cow has a significant impact on calf birth weight and daily gains during 
the rearing (Przysucha et al. 2002a, b, c, d; Przysucha and Grodzki 2004, 2007). Therefore, the weight of a cow in adulthood is an important trait to be considered for breeding programs (Andersen 1978; Brown et al. 1989). Breeding goals for most beef breeds are focused on massive cow with a high caliber.

Table 2. Body weight of purebred Simmental cows

Tabela 2. Masa ciała czystorasowych krów rasy simental

\begin{tabular}{cccccc}
\hline \multirow{2}{*}{$\begin{array}{c}\text { Year } \\
\text { Rok }\end{array}$} & $\mathrm{N}$ & \multicolumn{4}{c}{$\begin{array}{c}\text { Cow body weight } \\
\text { Masa ciała krowy [kg] }\end{array}$} \\
\cline { 3 - 6 } & 224 & $\min$ & max. & $\begin{array}{c}\text { average } \\
\text { średnia }\end{array}$ & SD \\
\hline 2000 & 213 & 430 & 730 & 574 & 66.0 \\
\hline 2001 & 274 & 420 & 700 & 590 & 68.2 \\
\hline 2002 & 312 & 400 & 710 & 589 & 53.9 \\
\hline 2003 & 393 & 440 & 700 & 590 & 51.3 \\
\hline 2004 & 109 & 495 & 710 & 591 & 46.7 \\
\hline $2005^{a}$ & 54 & 470 & 750 & 568 & 34.8 \\
\hline $2006^{a}$ & 467 & 615 & 522 & 32.2 \\
\hline
\end{tabular}

a Body weight after first calving - Masa ciała po pierwszym ocieleniu.

Table 3 shows how the average natal weight of calves. The average weight at birth of heifers in each year assessment was similar, but after 2009 began be lower than $33 \mathrm{~kg}$. In purebred bulls decrease in the average birth weight was noticed. The difference in birth weights between heifers and bulls ranged from 1 to $2 \mathrm{~kg}$ depending on year. The birth weight of calves has a significant effect on weaning weight of calves and usually the calf is heavier at birth the greater the weight at the time of weaning (Przysucha et al. 2002a, b, c).

Table 3. Average body weight of purebred heifers and bulls at birth

Tabela 3. Średnia masa ciała czystorasowych jałówek i buhajków po urodzeniu

\begin{tabular}{ccccccccccc}
\hline & & \multicolumn{8}{c}{ Body weight - Masa ciała [kg] } \\
\cline { 5 - 13 } $\begin{array}{c}\text { Year } \\
\text { Rok }\end{array}$ & $\begin{array}{c}\mathrm{N} \\
\text { heifers } \\
\text { jałówki }\end{array}$ & $\begin{array}{c}\mathrm{N} \\
\text { bulls } \\
\text { buhajki }\end{array}$ & $\begin{array}{c}\text { min. } \\
\text { heifers } \\
\text { jałówki }\end{array}$ & $\begin{array}{c}\text { min. } \\
\text { bulls } \\
\text { buhajki }\end{array}$ & $\begin{array}{c}\text { max. } \\
\text { heifers } \\
\text { jałówki }\end{array}$ & $\begin{array}{c}\text { max. } \\
\text { bulls } \\
\text { buhajki }\end{array}$ & $\begin{array}{c}\text { average } \\
\text { heifers } \\
\text { jałówki }\end{array}$ & $\begin{array}{c}\text { average } \\
\text { bulls } \\
\text { buhajki }\end{array}$ & $\begin{array}{c}\text { SD } \\
\text { heifers } \\
\text { jałówki }\end{array}$ & $\begin{array}{c}\text { SD } \\
\text { bulls } \\
\text { buhajki }\end{array}$ \\
\hline 2000 & 121 & 101 & 25 & 20 & 45 & 50 & 33 & 35 & 4.7 & 4.9 \\
\hline 2001 & 102 & 113 & 15 & 24 & 45 & 50 & 33 & 35 & 5.2 & 2.6 \\
\hline 2002 & 150 & 123 & 22 & 27 & 50 & 42 & 34 & 34 & 4.4 & 3.6 \\
\hline 2003 & 163 & 145 & 25 & 26 & 45 & 50 & 34 & 36 & 3.6 & 4.0 \\
\hline 2004 & 191 & 177 & 28 & 26 & 41 & 43 & 35 & 35 & 2.6 & 3.0 \\
\hline 2005 & 277 & 250 & 20 & 25 & 55 & 55 & 34 & 36 & 3.9 & 3.8 \\
\hline 2006 & 299 & 357 & 19 & 24 & 40 & 50 & 33 & 34 & 2.1 & 3.7 \\
\hline 2007 & 232 & 217 & 18 & 24 & 45 & 48 & 34 & 36 & 3.9 & 3.6 \\
\hline 2008 & 281 & 241 & 22 & 22 & 62 & 59 & 36 & 38 & 5.0 & 5.7 \\
\hline 2009 & 271 & 283 & 20 & 22 & 44 & 70 & 33 & 36 & 3.9 & 5.1 \\
\hline 2010 & 257 & 276 & 18 & 22 & 48 & 59 & 32 & 35 & 4.0 & 4.5 \\
\hline 2011 & 314 & 299 & 20 & 21 & 67 & 61 & 31 & 33 & 4.9 & 5.5 \\
\hline 2012 & 297 & 292 & 20 & 16 & 45 & 58 & 31 & 33 & 4.0 & 5.3 \\
\hline 2013 & 242 & 247 & 20 & 20 & 52 & 53 & 32 & 32 & 5.0 & 5.2 \\
\hline 2014 & 238 & 252 & 20 & 20 & 55 & 45 & 31 & 34 & 4.8 & 6.3 \\
\hline
\end{tabular}


Table 4 presents data on the average daily gains of heifers and bulls from birth up to 210 days of age. Average daily gains of heifers evaluated ranged from 818 to $1127 \mathrm{~g}$ in various years of assessment. While the average daily gains of bulls evaluated $(1100 \mathrm{~g})$ exceeded 12 times during the 15 years of the assessment. Analyzing the data presented, it should be noted the large difference between the minimum and maximum daily gains in both heifers and bulls. High average daily weight gains of bulls to 210 days of age means that at short extra supplementary fattening period of about one month allow to export the animals weighing about $300 \mathrm{~kg}$ at a good price. Dobicki (1996) study showed that the average daily gains of heifers (550-560 g), guarantee obtaining at 15 months of age body weight allowing the commencement of breeding.

Table 4. Average daily gains of purebred heifers and bulls to 210 days of age Tabela 4. Średni dobowy przyrost masy ciała jałówek i buhajków do wieku 210 dni

\begin{tabular}{|c|c|c|c|c|c|c|c|c|c|c|}
\hline \multirow[b]{2}{*}{$\begin{array}{l}\text { Year } \\
\text { Rok }\end{array}$} & \multirow{2}{*}{$\begin{array}{l}\mathrm{N} \\
\text { heifers } \\
\text { jałówki }\end{array}$} & \multirow{2}{*}{$\begin{array}{c}\mathrm{N} \\
\text { bulls } \\
\text { buhajki }\end{array}$} & \multicolumn{8}{|c|}{$\begin{array}{c}\text { Daily gains } \\
\text { Przyrost dobowy [g] }\end{array}$} \\
\hline & & & $\begin{array}{c}\text { min. } \\
\text { heifers } \\
\text { jałówki }\end{array}$ & $\begin{array}{c}\text { min. } \\
\text { bulls } \\
\text { buhajki }\end{array}$ & $\begin{array}{c}\text { max. } \\
\text { heifers } \\
\text { jałówki }\end{array}$ & $\begin{array}{c}\text { max. } \\
\text { bulls } \\
\text { buhajki }\end{array}$ & $\begin{array}{c}\text { average } \\
\text { heifers } \\
\text { średnia } \\
\text { jałówki }\end{array}$ & $\begin{array}{c}\text { average } \\
\text { bulls } \\
\text { średnia } \\
\text { buhajki }\end{array}$ & $\begin{array}{c}\text { SD } \\
\text { heifers } \\
\text { jałówki }\end{array}$ & $\begin{array}{c}\text { SD } \\
\text { bulls } \\
\text { buhajk }\end{array}$ \\
\hline 2000 & 43 & 29 & 540 & 598 & 1199 & 1383 & 915 & 950 & 191.1 & 179.5 \\
\hline 2001 & 90 & 77 & 639 & 649 & 1472 & 1486 & 1017 & 1152 & 222.4 & 268.4 \\
\hline 2002 & 43 & 29 & 619 & 647 & 1025 & 1010 & 818 & 839 & 109.6 & 92.5 \\
\hline 2003 & 93 & 90 & 633 & 672 & 1133 & 1286 & 879 & 998 & 96.1 & 128.7 \\
\hline 2004 & 152 & 129 & 512 & 564 & 1487 & 1782 & 1016 & 1169 & 163.6 & 229.0 \\
\hline 2005 & 170 & 158 & 560 & 710 & 1633 & 1623 & 1107 & 1201 & 156.2 & 122.3 \\
\hline 2006 & 130 & 290 & 671 & 638 & 1598 & 1947 & 1055 & 1240 & 128.9 & 231.2 \\
\hline 2007 & 183 & 164 & 691 & 872 & 1641 & 1507 & 1065 & 1159 & 159.9 & 138.7 \\
\hline 2008 & 307 & 231 & 654 & 794 & 1892 & 1529 & 1079 & 1178 & 167.3 & 131.1 \\
\hline 2009 & 288 & 309 & 436 & 736 & 1543 & 1633 & 1060 & 1199 & 150.1 & 136.2 \\
\hline 2010 & 258 & 245 & 759 & 750 & 1520 & 1540 & 1108 & 1256 & 146.6 & 124.3 \\
\hline 2011 & 271 & 239 & 606 & 712 & 1409 & 1550 & 1055 & 1235 & 107.5 & 133.9 \\
\hline 2012 & 265 & 217 & 900 & 909 & 1511 & 1687 & 1113 & 1330 & 72.7 & 178.0 \\
\hline 2013 & 233 & 230 & 574 & 1000 & 1415 & 1570 & 1015 & 1229 & 151.9 & 83.3 \\
\hline 2014 & 237 & 242 & 878 & 996 & 1437 & 1669 & 1127 & 1309 & 15.9 & 139.9 \\
\hline
\end{tabular}

Table 5 contains a summary of the terms of cows and heifers calving aptitude of analyzed breed in the following months of the year in 2000-2014. Seasonality in breeding beef herds calving aptitude is very important. because it allows more appropriate term of calving to receive in the future a very good quality breeding material with the least amount of cost of rearing (maximum utilization of pastures). Many authors believe (Dobicki 1996; Jasiorowski 1999; Jasiorowski and Przysucha 2004), that the period of mating and the resulting of calving aptitude time should not be longer than 2-3 months. Beef cows, maintained all year round in grazing system should make the best offspring in the winter. Calves born in the period after the completion of the first period of milk drinking are prepared to make full use of the pasture, then their growth rate is fast. Calves are healthy and good developed and breeder bear the smallest rearing costs. It should also be noted that in the winter calvings weaning calves moment coincides with the impoverishment of pastures in autumn. the consequence is natural dry-off pregnant cows. With winter calvings cows mostly deliver in the barn so that it 
is easier to monitor deliveries and possible assistance in the event of complications. Analyzing the obtained results and assuming that the most favorable period of cows calving aptitude is the period from December to March. It should be noted that since 2011 over $70 \%$ of the Polish Simmental cows delivered during the relevant period. It follows that still more than about $30 \%$ of the calves born at other times of the year only to a small degree can take full advantage of the pasture.

Table 5. Calving time of purebred cows and heifers

Tabela 5. Czas wycieleń czystorasowych krów i jałówek

\begin{tabular}{|c|c|c|c|c|c|c|c|c|c|c|c|c|c|c|}
\hline \multirow{2}{*}{$\begin{array}{l}\text { Year } \\
\text { Rok }\end{array}$} & & \multicolumn{12}{|c|}{$\begin{array}{l}\text { Months } \\
\text { Miesiące }\end{array}$} & \multirow{2}{*}{$\begin{array}{c}\text { Total } \\
\text { Razem }\end{array}$} \\
\hline & & 1 & II & III & IV & V & $\mathrm{VI}$ & VII & VIII & IX & $X$ & $\mathrm{XI}$ & XII & \\
\hline \multirow{2}{*}{2000} & $\mathrm{~N}$ & 8 & 34 & 58 & 36 & 36 & 16 & 15 & 6 & 6 & 7 & 2 & 1 & 225 \\
\hline & $\%$ & 3.6 & 15.1 & 25.8 & 16.0 & 16.0 & 7.1 & 6.7 & 2.7 & 2.7 & 3.1 & 0.9 & 0.4 & 100.0 \\
\hline \multirow{2}{*}{2001} & $\mathrm{~N}$ & 20 & 28 & 61 & 31 & 26 & 25 & 11 & 7 & 3 & - & 3 & 2 & 217 \\
\hline & $\%$ & 9.2 & 12.9 & 28.1 & 14.3 & 12.0 & 11.5 & 5.1 & 3.2 & 1.4 & - & 1.4 & 0.9 & 100.0 \\
\hline \multirow{2}{*}{2002} & $\mathrm{~N}$ & 29 & 37 & 85 & 53 & 26 & 12 & 11 & 8 & 8 & 7 & 3 & 2 & 281 \\
\hline & $\%$ & 10.3 & 13.2 & 30.2 & 18.9 & 9.3 & 4.3 & 3.9 & 2.8 & 2.8 & 2.5 & 1.1 & 0.7 & 100.0 \\
\hline \multirow{2}{*}{2003} & $\mathrm{~N}$ & 23 & 58 & 53 & 69 & 25 & 16 & 8 & 12 & 7 & 7 & 9 & 25 & 312 \\
\hline & $\%$ & 7.4 & 18.6 & 17.0 & 22.1 & 8.0 & 5.1 & 2.6 & 3.8 & 2.2 & 2.2 & 2.9 & 8.0 & 100.0 \\
\hline \multirow{2}{*}{2004} & $\mathrm{~N}$ & 35 & 42 & 108 & 57 & 23 & 30 & 40 & 19 & 12 & 4 & 6 & 18 & 394 \\
\hline & $\%$ & 8.9 & 10.7 & 27.4 & 14.5 & 5.8 & 7.6 & 10.2 & 4.8 & 3.0 & 1.0 & 1.5 & 4.6 & 100.0 \\
\hline \multirow{2}{*}{2005} & $\mathrm{~N}$ & 43 & 53 & 125 & 76 & 32 & 36 & 45 & 27 & 19 & 9 & 24 & 24 & 513 \\
\hline & $\%$ & 8.4 & 10.3 & 24.3 & 14.8 & 6.2 & 7.0 & 8.8 & 5.3 & 3.7 & 1.8 & 4.7 & 4.7 & 100.0 \\
\hline \multirow{2}{*}{2006} & $\mathrm{~N}$ & 54 & 66 & 78 & 77 & 66 & 65 & 55 & 56 & 56 & 13 & 35 & 32 & 653 \\
\hline & $\%$ & 8.3 & 10.1 & 11.9 & 11.8 & 10.1 & 10.0 & 8.4 & 8.5 & 8.5 & 2.0 & 5.4 & 4.9 & 00.0 \\
\hline \multirow{2}{*}{2007} & $\mathrm{~N}$ & 98 & 62 & 107 & 50 & 35 & 60 & 50 & 39 & 31 & 25 & 30 & 130 & 717 \\
\hline & $\%$ & 13.7 & 8.6 & 14.9 & 7.0 & 4.9 & 8.4 & 7.0 & 5.4 & 4.3 & 3.5 & 4.2 & 18.1 & 100.0 \\
\hline \multirow{2}{*}{2008} & $\mathrm{~N}$ & 73 & 101 & 67 & 68 & 56 & 57 & 38 & 25 & 23 & 17 & 41 & 77 & 643 \\
\hline & $\%$ & 11.4 & 15.7 & 10.4 & 10.6 & 8.7 & 8.9 & 5.9 & 3.9 & 3.6 & 2.6 & 6.4 & 12.0 & 100.0 \\
\hline \multirow{2}{*}{2009} & $\mathrm{~N}$ & 159 & 112 & 54 & 73 & 81 & 27 & 25 & 20 & 11 & 13 & 32 & 73 & 680 \\
\hline & $\%$ & 23.4 & 16.5 & 7.9 & 10.7 & 11.9 & 4.0 & 3.7 & 2.9 & 1.6 & 1.9 & 4.7 & 10.7 & 100.0 \\
\hline \multirow{2}{*}{2010} & $\mathrm{~N}$ & 151 & 67 & 110 & 88 & 41 & 38 & 18 & 7 & 6 & 8 & 36 & 49 & 610 \\
\hline & $\%$ & 24.4 & 10.8 & 17.8 & 14.2 & 6.6 & 6.1 & 2.9 & 1.1 & 1.0 & 1.3 & 5.8 & 7.9 & 100.0 \\
\hline \multirow[b]{2}{*}{2011} & $\mathrm{~N}$ & 234 & 98 & 67 & 52 & 36 & 21 & 17 & 11 & 7 & 7 & 46 & 96 & 692 \\
\hline & $\%$ & 33.8 & 14.2 & 9.7 & 7.5 & 5.2 & 3.0 & 2.5 & 1.6 & 1.0 & 1.0 & 6.6 & 13.9 & 100.0 \\
\hline \multirow{2}{*}{2012} & $\mathrm{~N}$ & 162 & 110 & 85 & 35 & 23 & 8 & 14 & 7 & 11 & 17 & 59 & 89 & 620 \\
\hline & $\%$ & 26.1 & 17.7 & 13.7 & 5.6 & 3.7 & 1.3 & 2.3 & 1.1 & 1.8 & 2.7 & 9.5 & 14.4 & 100.0 \\
\hline \multirow{2}{*}{2013} & $\mathrm{~N}$ & 103 & 101 & 63 & 29 & 17 & 11 & 3 & 6 & 13 & 4 & 60 & 96 & 506 \\
\hline & $\%$ & 20.4 & 20.0 & 12.5 & 5.7 & 3.4 & 2.2 & 0.6 & 1.2 & 2.6 & 0.8 & 11.9 & 19.0 & 100.0 \\
\hline \multirow[b]{2}{*}{2014} & $\mathrm{~N}$ & 135 & 108 & 57 & 32 & 10 & 6 & 10 & 8 & 1 & 5 & 53 & 130 & 555 \\
\hline & $\%$ & 24.3 & 19.5 & 10.3 & 5.8 & 1.8 & 1.1 & 1.8 & 1.4 & 0.2 & 0.9 & 9.5 & 23.4 & 100.0 \\
\hline
\end{tabular}

Table 6 shows the percentage distribution of calving aptitude of purebred Simmental cows according to calving order. The greatest number of cows calved in the years of evaluation was reported in primiparous cows and cows calving for the second time. It should be noted that in 2000 primiparous cows and the animals calving for the second time constituted more than $50 \%$ and in $201435 \%$ of the population. It means that the life of the cow increases, which is of particular economic importance. Long life of cows in herds of beef cattle is one of the main factors allowing for reducing the cost. so the breeders should try to use cows as long as possible. 
Table 6. Distribution of calvings related to the order of calving

Tabela 6. Rozkład wycieleń w zależności od kolejności ocielenia

\begin{tabular}{|c|c|c|c|c|c|c|c|c|c|c|c|c|c|c|}
\hline \multirow{2}{*}{$\begin{array}{l}\text { Year } \\
\text { Rok }\end{array}$} & & \multicolumn{12}{|c|}{$\begin{array}{l}\text { Months } \\
\text { Miesiące }\end{array}$} & \multirow{2}{*}{$\begin{array}{c}\text { Total } \\
\text { Razem }\end{array}$} \\
\hline & & 1 & 2 & 3 & 4 & 5 & 6 & 7 & 8 & 9 & 10 & 11 & $\geq 12$ & \\
\hline \multirow{2}{*}{2000} & $\mathrm{~N}$ & 66 & 56 & 24 & 74 & 5 & - & - & - & - & - & - & - & 225 \\
\hline & $\%$ & 29.3 & 24.9 & 10.7 & 32.9 & 2.2 & - & - & - & - & - & - & - & 100.0 \\
\hline \multirow{2}{*}{2001} & $\mathrm{~N}$ & 41 & 54 & 36 & 27 & 54 & 4 & - & - & - & - & - & - & 216 \\
\hline & $\%$ & 19.0 & 25.0 & 16.7 & 12.5 & 25.0 & 1.9 & - & - & - & - & - & - & 100.0 \\
\hline \multirow{2}{*}{2002} & $\mathrm{~N}$ & 58 & 46 & 69 & 38 & 28 & 39 & 3 & - & - & - & - & - & 281 \\
\hline & $\%$ & 20.6 & 16.4 & 24.6 & 13.5 & 10.0 & 13.9 & 1.1 & - & - & - & - & - & 100.0 \\
\hline \multirow{2}{*}{2003} & $\mathrm{~N}$ & 108 & 34 & 43 & 47 & 26 & 19 & 21 & 3 & & & & & 301 \\
\hline & $\%$ & 35.9 & 11.3 & 14.3 & 15.6 & 8.6 & 6.3 & 7.0 & 1.0 & - & - & - & - & 100.0 \\
\hline \multirow{2}{*}{2004} & $\mathrm{~N}$ & 105 & 102 & 40 & 46 & 47 & 20 & 12 & 21 & 1 & - & - & - & 394 \\
\hline & $\%$ & 26.6 & 25.9 & 10.2 & 11.7 & 11.9 & 5.1 & 3.0 & 5.3 & 0.3 & - & - & - & 100.0 \\
\hline \multirow{2}{*}{2005} & $\mathrm{~N}$ & 148 & 96 & 93 & 38 & 48 & 43 & 22 & 8 & 17 & - & - & - & 513 \\
\hline & $\%$ & 28.8 & 18.7 & 18.1 & 7.4 & 9.4 & 8.4 & 4.3 & 1.6 & 3.3 & - & - & - & 100.0 \\
\hline \multirow{2}{*}{2006} & $\mathrm{~N}$ & 54 & 211 & 203 & 121 & 23 & 10 & 9 & 5 & 6 & 7 & 4 & - & 653 \\
\hline & $\%$ & 8.3 & 32.3 & 31.1 & 18.5 & 3.5 & 1.5 & 1.4 & 0.8 & 0.9 & 1.1 & 0.6 & - & 100.0 \\
\hline \multirow{2}{*}{2010} & $\mathrm{~N}$ & 115 & 103 & 108 & 80 & 65 & 55 & 40 & 26 & 11 & 8 & 8 & - & 619 \\
\hline & $\%$ & 18.5 & 16.6 & 17.4 & 12.9 & 10.5 & 8.8 & 6.4 & 4.2 & 1.7 & 1.2 & 1.2 & - & 100.0 \\
\hline \multirow{2}{*}{2011} & $\mathrm{~N}$ & 91 & 105 & 105 & 114 & 88 & 57 & 46 & 37 & 23 & 7 & 7 & 3 & 692 \\
\hline & $\%$ & 13.1 & 15.1 & 16.4 & 16.4 & 12.7 & 8.2 & 6.6 & 5.3 & 3.3 & 1.0 & 1.0 & 0.3 & 100.0 \\
\hline \multirow{2}{*}{2012} & $\mathrm{~N}$ & 97 & 82 & 72 & 90 & 90 & 64 & 42 & 30 & 24 & 17 & 3 & 9 & 620 \\
\hline & $\%$ & 15.6 & 13.2 & 11.6 & 14.5 & 14.5 & 10.3 & 6.7 & 4.8 & 3.8 & 2.7 & 0.4 & 1.4 & 100.0 \\
\hline \multirow{2}{*}{2013} & $\mathrm{~N}$ & 74 & 82 & 66 & 38 & 57 & 70 & 42 & 28 & 20 & 12 & 13 & 4 & 506 \\
\hline & $\%$ & 14.6 & 16.2 & 13.0 & 7.5 & 11.3 & 13.8 & 8.3 & 5.5 & 4.0 & 2.4 & 2.6 & 0.8 & 100.0 \\
\hline \multirow{2}{*}{2014} & $\mathrm{~N}$ & 127 & 67 & 77 & 65 & 41 & 52 & 53 & 26 & 20 & 11 & 7 & 9 & 555 \\
\hline & $\%$ & 22.9 & 12.1 & 13.9 & 11.7 & 7.4 & 9.4 & 9.5 & 4.7 & 3.6 & 2.0 & 1.3 & 1.6 & 100.0 \\
\hline
\end{tabular}

\section{RECAPITULATION}

One can observe a gradual decline in the share of the national Simmental beef cattle population. it also shows a significant decrease in the number of crossbreds with Simmental breed. The average weight of cows in 2005-2006 amounting to 568.5 and $522.5 \mathrm{~kg}$ meet the breeding standards for of cows entered in the initial part of the herd book, which define the minimum weight of Simmental cows after first calving as $470 \mathrm{~kg}$. The average weight at birth of heifers in each year assessment was similar, but after 2009 began be lower than $33 \mathrm{~kg}$. In purebred bulls decrease in the average birth weight was noticed. The difference in birth weights between heifers and bulls ranged from 1 to $2 \mathrm{~kg}$ depending on year. Average daily gains of heifers evaluated ranged from 818 to $1127 \mathrm{~g}$ in various years of assessment. While the average daily gains of bulls evaluated $(1100 \mathrm{~g})$ exceeded 12 times during the 15 years of the assessment. The average daily gains of heifers (550-560 g), guarantee obtaining at 15 months of age body weight allowing the commencement of breeding. Since 2011 over $70 \%$ of the Polish Simmental cows delivered during the relevant period.

\section{REFERENCES}

Andersen B.B. 1978. Animal size and efficiency. with special reference to growth and feed conversion in cattle. Anim. Prod. 27, 381-391.

Brown C.J., Johnson Z.B., Brown A.H. Jr. 1989. Between and within breed variation in mature weight and maturing interval of beef cattle. J. Anim. Sci. 67 (Suppl. 2), 9. 
Dobicki A. 1996. Hodowla i użytkowanie bydła ras mięsnych [Beef cattle breeding]. Chów Bydła 11, 9-20. [in Polish]

Jasiorowski H. 1999. Blaski i cienie hodowli bydła mięsnego w Polsce [Highlights and shadows of beef cattle breeding in Poland]. Wieś Jutra 7-8, 27-28. [in Polish]

Jasiorowski H., Przysucha T. 2004. Bydło mięsne: wybór rasy [Beef cattle: breed choice]. Top Agrar. Pol. 1. 102-104. [in Polish]

Jasiorowski H., Kijak Z., Poczynajło S., Wajda S. 1996. Program rozwoju hodowli bydła mięsnego w Polsce. Warszawa, Fundacja "Rozwój SGGW", 5-67. [in Polish]

Krajowe Centrum Hodowli Zwierząt. 1997-2000. Ocena wartości użytkowej krów oraz ocena i selekcja buhajów. Wyniki za lata 1996-1999. Warszawa, KCHZ. [in Polish]

Polski Związek Hodowców i Producentów Bydła Mięsnego. 2001-2014. Ocena wartości użytkowej bydła ras mięsnych. Wyniki za lata 2000-2013. Warszawa, PZH i PBM. [in Polish]

Przysucha T., Czarnecki Vel Sarnecki M., Grodzki H., Zdziarski K. 2002b. The influence of selected factors on body weight and daily gains of Angus calves. Rocz. Nauk. Zoot. 15(Suppl.), 225-230.

Przysucha T., Czarnecki Vel Sarnecki M., Grodzki H., Zdziarski K. 2002a. Analiza wpływu wybranych czynników na tempo wzrostu cieląt rasy hereford [The influence of chosen factors on growth rate of Hereford calves]. Zesz. Nauk. Prz. Hod. 60. 233-243. [in Polish]

Przysucha T., Grodzki H., Charłampowicz A., Zdziarski K. 2002c. The effect of selected factors on growth rate of Limousine calves. Anim. Sci. Pap. Rep. 20(1) Suppl., 221-228.

Przysucha T., Grodzki H., Nałęcz-Tarwacka T., Zdziarski K. 2002d. Analiza wpływu wybranych czynników na masę ciała i przyrosty cieląt rasy charolaise [The influence of chosen factors on body weight and growth rate of Charolaise calves]. Zesz. Nauk. Prz. Hod. 62, 203-210. [in Polish]

Przysucha T., Grodzki H. 2004. The influence of selected factors on growth rate of Charolais and Simmental calves. Electron. J. Pol. Agric. Univ., Ser. Animal Husbandry 7(1).

Przysucha T., Grodzki H. 2007. Wpływ wybranych czynników na przebieg porodów krów rasy simental [Influence of chosen factors on the course of the calving of Simmental cows]. Med. Weter. 63(8), 960-962. [in Polish]

Abstract. The aim of the study was to assess the utility of selected results of Simmental breed with respect to their compliance with the goal of racial breeding and standards adopted by the Polish Association of Breeders and Producers of Beef Cattle (PABPBC). The subject of the analysis were recording results of the Simmental beef cattle breed. The study was based on data for the years 2002-2014 of PABPBC and the National Center of Animal Breeding (NCAB) for 2000-2001. Evaluated properties are: average weight of cows [kg], the average body weight of calves after birth [kg], the terms of cows and heifers calving aptitude, the distribution of the population according to the order of calving cows. The average weight of cows in 2005-2006 amounting to 568.5 and $522.5 \mathrm{~kg}$ meet the breeding standards for of cows entered in the initial part of the herd book. which define the minimum weight of Simmental cows after first calving as $470 \mathrm{~kg}$. The average weight at birth of heifers after 2009 began be lower than $33 \mathrm{~kg}$. In purebred bulls decrease in the average birth weight was noticed.The average daily gains of heifers $(550-560 \mathrm{~g})$, guarantee obtaining at 15 months of age body weight allowing the commencement of breeding. 